\title{
Positioning oneself and being positioned in the 'community' An essay on Jewish ethnography as a 'Jew-ish' ethnographer
}

\author{
BEN KASSTAN
}

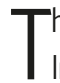
his article offers a reflexive and anthropological contribution to the current volume of Scripta Instituti Donneriani Aboensis. It reflects on the experience of conducting anthropological work at home - or across homes - I considered this research to be an experience of 'Jewish ethnography' as a Jewish ethnographer. However, my own 'Jew-ish' background meant that I had become 'neither fish nor fowl' within the field-site, which proved both to be an obstacle to, and an opportunity for, conducting the research. It utilises this experience to challenge the conceptual use of the term 'community', which encapsulates considerable diversity but obscures the nuanced differences that can pervade a social body. These reflections demonstrate how positionality can be used as a tool for postgraduate students to untangle the complexities of conducting ethnographic research at 'home' or in relation to religious minority groups, where significant intra-group differences of practice and worldviews exist, but may otherwise be concealed by the image of 'community'.

\section{Preface}

Haredi Jewish minorities are often grouped together and framed by public health bodies in England and Europe as the 'ultra-Orthodox Jewish community' with not much clarity concerning of how this 'community' is constituted. I was consequently interested to problematise the construction in health discourse of this composite collective as a 'community' and the implications of this for meeting their needs. Presenting my initial findings at the Donner Institute in March 20I 5 for a round-table discussion on 'Judaic Studies in the Nordic Countries Today' was, then, a timely opportunity to reflect on my $\mathrm{PhD}$ fieldwork which was conducted in an Orthodox and Haredi Jewish area of England, introduced above and discussed in this essay.

Although this volume shows an unfortunate lack of anthropological or ethnographic perspectives of Jewish sociality in the Nordic countries or by Nordic scholars, anthropological contributions to Jewish studies more broadly have been immense. Anthropologists have certainly contributed to the sub-field of 
Jewish studies by producing research that critically analyses emerging encounters within Jewish social worlds, as well as intra- and inter-community relations as they connect, conflict, or coalesce over time (to name just a few examples; see Arkin 2014, Egorova and Perwez 2013, Goldberg I972, Herman 201 2, Sered 1996). It has also proved to be a stimulating and reflexive journey when the researcher conducts anthropology at 'home' or has a degree of relation to the context of study, as prompted by Barbara Myerhoff's (1978) legendary ethnographical work Number Our Days (see also Fader 2009, Kugelmass I 988, Kahn 2000, Seeman 2009, Stadler 2009, Weiss 2002).

As a growing and prominent Jewish minority, the "ultra-Orthodox community' has increasingly become the focus of academic interest. In the context of Israel, its members have been cited as being an example of 'Jewish fundamentalism', demonstrating outward expressions of activism and resistance despite voluntarily living 'in sort of ghettos that have ecological and cultural boundaries clearly defined and carefully maintained' (Aran et al. 2008: 32; see also Hakak 2009, 20 I I). There remains, however, a lack of ethnographic research that captures the texture of Jewish life in the UK (also argued by Kahn-Harris 20I4), particularly regarding the bounds of Orthodox and Haredi Judaism.

Rather than a fixed 'boundary', the term 'frontier' accounts for a situation that is brought about by the presence of 'overlapping and moving cultures' (see, for instance, Merli 2008: 6), which could, more suitably, describe a composite collective that is formed of multiple Jewish modalities. Ethnographic research and the researcher's experience of positionality may then be a strategic method for teasing out the complexities and intricacies of Jewish topographies that are not defined by the notion of a clear-cut and contained 'community'.

Following a year of immersive fieldwork, my own experience of Jewish ethnography as a 'Jew-ish' ethnographer has consequently challenged the notion of a Jewish 'community' as a construct and also how it is employed in health discourse as well as Jewish studies. The article reflects on the process of negotiating one's position when pursuing anthropological research 'at home' or across homes, in this case, as I conducted research both in the UK and within Jewish contexts that cannot be singularly defined. It offers an insight into the potential of anthropological research methods for postgraduate students in Jewish studies, as well as understanding the complexities of Jewish social bodies in Europe today. 


\section{Anthropology across homes: being 'neither fish nor fowl'}

It has been noted that the motivations for pursuing anthropological work at home might be because 'many of the people we study are those with whom we most closely identify: people of our ethnic group or subculture, people with our same social class, history, and traditions' (Messerschmidt I98 I: 8). Conducting 'anthropology at home' certainly encourages an individual to consider how fieldwork will be approached and what research methods will be employed, but also to confront the meaning of 'home' and how it is conceptualised. The ways in which 'home' as a field-site (and the field-site as a home) is perceived, experienced, and envisaged consequently shapes the relationships that are built with research participants, which is so crucial to anthropological work. But how is fieldwork at 'home' conceived of when the researcher and participants have differing perceptions of who belongs and who does not?

'Home', as Michael Jackson describes it, 'is a double-barreled word. It conveys a notion of all that is already given - the sedimented lives of those who have gone before - but it is also conveys a notion of what is chosen - the open horizons of a person's own life' (I 995: I 22). Spurred perhaps by the feeling of biraeth (Welsh, 'a longing for a lost home'), researchers who conduct anthropological work at home may then choose a field-site in which to sojourn based on a nostalgic, internalised, or even imagined bond to the social or physical topography. This has certainly been the case in Jewish ethnography, as expressed by Jonathan Boyarin, 'I will hazard a guess that Jewish anthropologists - perhaps anthropologists in general - are motivated by a sense of loss' (I 988: 73).

Defining 'home', for me, has been a constant challenge. Not only did I grow up away from the UK and live in Mauritius, Djibouti, Benin, Botswana, and Lesotho, but the familial roots sown by my forbears also span countries, continents, and religious traditions. My own family narrative crosses ancestral homelands; being uprooted and dispossessed has been a feature of my family narrative for generations, as is typical of many Jewish families. Home is therefore a nostalgic memory that has been handed down from generation to generation; it is a physical absence, augmented by a spiritual distance from an expression of Judaism that I imagined as more 'traditional'. On reflection, it was most probably this physical and spiritual nostalgia which prompted me to pursue Jewish ethnography twice over, first as a Masters student and then as a $\mathrm{PhD}$ candidate.

Durham University in the north of England has been the 'home' that I have been raised in as a student over the last seven years, and here I received all of my methodological and theoretical training - right from undergraduate to $\mathrm{PhD}$ level. 
In May 20I4 it was time to pack up years of preparatory notes and relocate for ethnographic fieldwork in an Orthodox and Haredi Jewish constituency, my chosen 'home' for the next twelve months. From this perspective, I was indeed conducting 'anthropology at home' as the academy and field-site that underlie my thesis and this ethnographic essay are both in the UK and just $\mathrm{I} 32$ miles apart. However, I quickly found that my own positioning, and indeed how I was positioned in the field-site, was a continuous process of negotiation and navigation which created a social distance that was constantly in a state of flux.

My formative ventures in Jewish ethnography as a Jewish ethnographer felt like I was undertaking 'anthropological work in the spiritual as well as the physical sense of the word "home" (Kasstan 201 5: 353). I perceived the fieldsite as being another sort of 'home' by proxy or extension of my Jewish heritage, and I (naively) expected a smoother process of immersion and integration into the field. This was imagined partly because of past fieldwork experiences and also an exposure to the values of Orthodox Judaism through my paternal Jewish relatives, but also because of a key passage inscribed in the Torah:

When a stranger resides with you in your land, you shall not wrong him.

The stranger who resides with you shall be to you as one of your citizens, you shall love him as yourself, for you were strangers in the land of Egypt. ([Tanakh] Leviticus I9:33-4)

The above edict on strangers, I was later told by a Haredi research participant, can be interpreted as only applying to bona fide Jews. And this was part of a harder lesson I received when working in the context of a strictly religious form of Jewish ethnography; my own Jewish identity would present both obstacles to and opportunities for the research.

Being Jewish by halachic ${ }^{1}$ definition is determined matrilineally in the Orthodox and Haredi streams of Judaism, and conversion is a contentious issue as only those performed under a 'reputable' Orthodox rabbinical authority are accepted. ${ }^{2}$ There is evidently no unanimous standard for conversion into Orthodox and Haredi Judaism, though it is important to note that balachah is just one definition of Jewish status. As a 'patrilineal Jew' under the auspices

1 Codex of rabbinical law (sing. halachab; pl. balachot).

2 Reference to 'reputable' taken from the United Synagogue (nd). Whilst Judaism is not a proselyting religion, giyur (Hebrew 'conversion', from the root ger meaning 'stranger', commonly interpreted as 'convert') is tolerated. A conversion performed under one 'Bet Din' (Hebrew 'House of Judgment') is not unanimous and does not mean recognition by another Bet Din or denomination. 
of Liberal Judaism ${ }^{3}$ - a leading progressive denomination that upholds Jewish status as equilineal - I presented as an anomaly because I was not acknowledged as Jewish, yet openly practised Judaism and could mobilise an understanding of the law, customs, and Hebrew language. It frequently seemed as if I embodied the threats which Orthodox, and particularly Haredi, Judaism seeks to insulate itself from; integration, assimilation, and most grievous of all, intermarriage. Liminality is often constructed as being 'dangerous, inauspicious, or polluting' (Turner 2002: 368) and I was, according to one participant, a grey area in a lifeworld defined and ordered by halachot.

I then became entangled in a conflict of (in)authenticity within the fieldsite; research participants would hold their authenticity against me and, in turn, the inauthentic was then constructed through me as a medium. Being nonJewish, and the threats of the external world, came to be defined by my behaviour and balachic status. At the core of this issue is the view that Orthodox and Haredi Jews are the authoritative, authentic, and legitimate practitioners of Judaism, who are arguably intolerant and prejudiced towards non-Orthodox Jewish modalities. ${ }^{4}$ The situation I encountered can be contextualised within a body of anthropological work that has explored contested definitions of, and dogma concerning, Jewish status, particularly in the case of Israel (see Seeman 2009, Egorova 2009), and thus upholds the view that the 'argument is not really about "who is a Jew?" but rather "who is to decide who is a Jew?"' (Alderman 2008: 9).

Also bound up in these discussions are the terms used to describe observant practitioners of Judaism, and the hierarchy of religious observance that they can insinuate. A common synonym for Haredi Jews is 'ultra-Orthodox', but this can be considered an inaccurate description for several reasons. In their cosmology there is nothing 'ultra-Orthodox' about living a life of 'Torah Judaism', which is supposedly conducted in accordance with the unadulterated values and laws inscribed in religious texts. ${ }^{5}$ In fact, this sub-group of religious practitioners generally prefer to regard themselves as 'Haredi', a term that is rooted in the Torah as 'those who tremble at God's word' (Isaiah 66:5). The more commonly

3 Liberal Judaism in the UK closely resembles the Reform Movement in the US, who both uphold Jewish status as being equilineal; that is, passed through both or either parent. The UK's Movement for Reform Judaism has recently taken measures to legitimise patrilineal Jews through a new process of 'certification' (see Rashty 20 I 5 ).

4 See Ferziger 2009 for a deeper discussion on Orthodox and Reform Jewish relations in the US context.

5 See Shapiro 2015, who argues that particular Orthodox establishments 'rewrite' history to suit current worldviews and conducts. 
used term 'ultra-Orthodox' can also be considered problematic because it implies the idea of one group being more observant than their (perhaps equally observant) co-religionists; the issue at hand is not the degree of observance but rather conceptual or cosmological differences in the essence of Judaism between the sub-groups. ${ }^{6}$

I initially reflected on the experience of Jewish anthropologists who conducted ethnographical research within Jewish communities for support on how to navigate issues in social interaction, and also the ways in which they personally identified with their field-sites (Myerhoff I978, Winston 2005, Stadler 2009, 20I3). However, I found this material did not fully relate to my position of a contested Jewish status. On the other hand, reflections by William E. Mitchell ( 1988 ) of being a 'goy in the ghetto' also did not reflect my liminal position within the field-site as I was not a complete outsider to the socioreligious context under study.

As Orthodox and Haredi Judaism places specific obligations and legal duties on co-religionists which those perceived as non-Jews are not encumbered with, I then found that some research participants used particular methods to reinforce their positioning of me. One such example was Shabbat observance, and being used as a 'Shabbos goy', 7 or being referred to as a sheigetz; a derogatory Yiddish word for a non-Jewish male, originating from the Hebrew term sheketz, meaning impure or abominable. The status I was ascribed proved to be an obstacle when engaging with some potential research participants, especially when authoritative figures would advise families to exclude or disinvite me from meals during Shabbat or chagim (festivals). This was particularly limiting as these invitations were typically the most opportune events at which to meet Jewish locals and engage in conversation about the research. The schism between how I positioned myself and how I was positioned in the field therefore epitomised the view that 'even for those of us who study our own ethnic group, the distance between the anthropologist and the "natives" remains' (Tsuda 20 I 5: I 5).

The status of 'neither fish nor fowl,' as one of my research participants described me, was an accurate reflection of my 'betwixt and between' position(ing). Conducting Jewish ethnography as a Jewish ethnographer soon became conducting Jewish ethnography as a 'Jew-ish' ethnographer, and was an experience that tested and tormented my own identity and subjectivity.

6 See translator's note by Haim Watzman (E1 Or 1994).

7 Shabbat (Sephardic pronunciation), Shabbos (Yiddish or Ashkenazi pronunciation); the Sabbath. Using a non-Jewish person (determined by halacbic status) to perform tasks that a Jewish person is prohibited from doing on Shabbat. 
Although these ethnographic encounters were personally challenging, they were, as has been argued previously, a necessary part of enabling an anthropologist-in-training to gain a sense of 'the host culture and its behavioural parameters' (Mitchell I 988: 228).

Conducting anthropology across homes caused 'boundaries' between oneself and the field, oneself and the research participants, as well as with one's quotidian or ritual facets of life, to constantly be re-drawn and instead reflected the fluidity of a 'frontier'. Moving from a progressive to an Orthodox and Haredi context of Judaism entailed abiding by Orthodox standards and customs, especially in relation to gender and dress. I also took a 'leap of faith' and stopped attending Liberal Jewish religious services during the twelve-month period in order to understand the context in which the research was grounded, and attending Orthodox and Haredi synagogues soon illuminated the extent of the socio-religious diversity that existed in a so-called 'community'.

The composite nature of the field-site, which is described in more depth in the following section, 'Anthropology across "communities", meant that I had to continuously negotiate what situations with the opposite gender would be acceptable and what would not. This was especially the case considering that Orthodox and Haredi Judaism uphold the strict separation of genders, and that specific doctrines are mobilised to minimise those interactions or degrees of engagement. On many occasions, for instance, I invited research participants for breakfast or a late lunch in the local kosher ${ }^{8}$ cafes as an act of gratitude for their time. However, it was a constant challenge to comprehend which research participants this would be (un)acceptable to, regarding the stringencies they applied to interactions with the opposite gender, and what could be misconstrued as being inappropriate by witnesses. Moreover, meeting in public cafes also ran the risk of conversations being overheard.

Regardless of the social or geographical proximity of the researcher to the area under study, it remains the case that ethnographic fieldwork 'requires us to ... embark on the uncomfortable process of learning about persons and power from scratch and often through mistakes and manifest ignorance' (Simpson 2006: I 26).

Anthropological work at home is not exempt from this process of navigating the field-site and its internal dynamics of power and potential. In fact,

Kashrut, laws governing food preparation and consumption. The kosher cafes in the field-site are under the supervision of different Bet Din who might apply - or are considered to apply - different stringencies to kashrut, so what might be considered kosher for one participant could be considered not kosher enough for another. 
it arguably adds further layers of complexity, as the researcher's subjectivity undergoes a transitional role in becoming an ethnographer at home, negotiating dualities in identities and status, and (re)aligning relationships along the way. Moreover, this is especially the case if we consider fieldwork as an 'initiatory rite' of social anthropology, where 'unless one proves oneself in the field, one has not earned the right to call oneself an anthropologist'(Jackson 20 I 2:4).

\section{Anthropology across 'communities'}

The above discussion does not imply that the field-site was a simple demarcation between those perceived as Jewish or non-Jewish, and the negotiation of my own identity was arguably characteristic of the field-site, where a multiplicity of Orthodox and Haredi Jewish groups sat 'cheek by jowl'. There was no singular expression of Judaism (or of being Orthodox or Haredi Jewish) in the field, and understanding the intra-group dynamics and diversity was a consistently arising element of the research to consider. This can be epitomised by a close participant, who, upon describing the field-site, remarked that there were 'fifty shades of grey here'.

Past ethnographic studies of Orthodox Jewish topographies have made similar claims, where "what looks like a single "suburban Orthodox Jewish community" is in fact a much more complex agglomeration of many communities' (Diamond 2008: I 20). As Etan Diamond (2008) notes, the Orthodox Jewish topography consists of 'religious microspaces' which are exclusive as well as encompassing of intra-group diversity, and this research not only involved understanding the myriad 'microspaces' and how they relate to each other, but also an attempt to access them as an 'outsider', build rapport, and develop potential research participants.

A previous study of a Haredi Jewish area in Manchester referred to the intra-group diversity as a situation where 'clearly there are communities within communities, but the imagination of an idealistic overall community remains' (Valins 2003: 167). My participants were quick to describe the Jewish area under study as a friendly 'community'; the fabric of society is indeed rich and tightly woven (perhaps for those considered to be on the 'inside'), and this was demonstrated by religious events which brought different facets of the population together and thus formed a principal area of interaction.

9 A reference to the controversial book and especially the film Fifty Shades of Grey, released in 2015 , at the time of the fieldwork. 
The festival of Purim was one vibrant example of this, where the local geography transformed into a carnival with open homes and institutions, and with mishloach manot ${ }^{10}$, alcohol, and donations flowing across frontiers. Interestingly, children attending particular schools would be in identifiable costumes; with boys from one institution all dressed in red and white stripes from the iconic book Where's Wally? those from another dressed as penguins, or another dressed as musketeers and adorned with fleurs de lis.

Whilst the space was quickly regarded as a 'friendly community' during the interviews, they also unravelled subtle threads of distinction. Rather than a 'community' - as the Jewish population in the UK is often and problematically referred to ${ }^{11}$ - I found that the field-site consisted of overlapping and multilayered sub-groups who sat side by side, and often with tensions between them. Moreover, conducting anthropological work across 'communities' challenged and undermined this term, as moving between sub-groups exposed the internal dissent and dissonance, and degrees of separation that were perceived to be necessary for (and protective of) the Haredi and especially the Hassidish ${ }^{12}$ cosmologies. Moving beyond the use of 'community' as a social and conceptual category was, then, an important part of the research, which enabled me to envisage the plurality of subjectivities as well as the relationships between the subgroups, and not only with each other, but also the broader non-Jewish environment.

Described as an 'ultra-Orthodox Jewish community' as it is by the English and European health authorities, there is indeed a risk of generalising and simplifying what is actually a complex and composite social body. Moreover, this raises questions of theoretical importance concerning the dynamics of this so called 'ultra-Orthodox Jewish community' and the conditions that make it 'hard to reach'.

There were mixed responses to the notion of being 'hard to reach' when I put this to my participants. One Haredi mother felt uneasy about being categorised as 'hard to reach', perhaps alongside other minority groups such as the historically stigmatised Roma and Irish travellers, and exclaimed 'it makes us sound like hippies or something'. Others commented that the self-insulating stance of the Haredi cosmology is a deliberate strategy, but social conducts that

10 Hebrew 'gifts of food that are given to friends and family on Purim'.

11 See Kahn-Harris and Gidley 2oro for a discussion on the 'Jewish community'.

12 Hassidish (used in the field-site as opposed to 'Hassidic', perhaps reflecting a linguistic and Yiddish reference) sub-groups are Haredi per definition, but not all Haredi Jews are Hassidish. 
non-Haredi Jews incorrectly interpret as being offensive is, I am told, in fact defensiveness on the part of the Haredim. As a key Hassidish authority, who is an integral part of the Haredi institutional landscape, made clear; 'I'm hoping what I've said to you is that I'm talking about communities trying to cope but on the other hand, it's a community that is vulnerable'.

Attention to intra-group diversity encourages a discussion on marginalities and the position of, and dissidence between, minorities within what is perceived as a singular and homogenous minority group. Conducting anthropological work across 'communities' within the field-site illustrated the differences in socio-religious conduct or worldviews that could be found across families, or what might be attributable to membership of a particular sub-group. One's worldview or hashkofab ${ }^{13}$, in turn, impacts upon the degree of engagement with the wider Jewish and non-Jewish population and institutions. Based on my ethnographic research and the preliminary findings that are presented here, intra-group diversity can consequently present challenges for the design and implementation of peer-led as well as state-provided health and wellbeing services, as health conduct cannot be considered in isolation but rather as part of cosmological or world view.

My initial attempts to relate sub-groups to each other and gauge the different standards of Orthodoxy were challenging as the continuum of being 'Orthodox' or 'ultra-Orthodox' was indeed vast. As one Haredi participant remarked, the most basic measure of Orthodoxy was being observant of the laws surrounding Shabbat and kashrut, and this prerequisite extended over to particular needs relating to individual or communal ideals of religious observance, such as gender-segregated or culturally sensitive services.

Signifiers such as 'Modern Orthodox', 'Orthodox', 'Haredi', and 'Hassidish' did not always position sub-groups as existing within clearly defined 'boundaries' but instead exemplified how frontiers could be flexible and fluid. In Mrs Rosen's $^{14}$ case, there was a reluctance to be identified as being Haredi and she instead identified her family as being on the 'Orthodox spectrum. We're frum Orthodox Jews. From the outside we'd be classed as Haredi, but Haredi is such an extreme and we're probably somewhere at the sort of lower end of the extreme'.

13 To reflect vernacular of the Jewish constituency under study, I use the Ashkenazi Yiddish pronunciation. This term was often pronounced as hashkofah (pl. hashkofos) in the field-site rather than the Sephardic pronunciation of hashkafah (pl. hashkafot).

14 All names in this paper have been replaced with pseudonyms in accordance with the ethical guidelines outlined by the ASA (20 I I). 
The word frum that Mrs Rosen refers to is the Yiddish term for pious, which was at first a challenging word to comprehend as it was often used as a standard of religious observance. The term was also used to demarcate individuals or institutions which were perceived as anti-frum, or what was considered as not being compliant with particular interpretations or stringencies of religious law; notably a local Jewish publication that advertised non-kosher restaurants or included images of women. I soon found that being frum did not necessarily entail abiding by religious dogma and prescribed texts alone, but also conforming to social norms and expectations. An integral part of frum life and its rich social fabric is 'community' (see Benor 2012), the membership of which commands conformity in dress, language, and restrained use of, for example, the internet and secular media. This is iconic of the notion of boundaries within ethno-cultural groups, where Frederik Barth noted that the identification of another person as a fellow member of an ethnic group implies a sharing of criteria for evaluation and judgment' (1 998: I 5). Abiding by frum values and social codes was then, interestingly enough, not always an indicator of acting in congruence with religious commandments, therefore demonstrating how 'emblematic labels and stereotypes of collective identity do not always provide reliable instruments of diagnosis of how people experience their own social identity, or that of other groups' (Jacobson-Widding I983:23).

By circulating around various social bodies and hashkofos within the fieldsite I was able to understand vernacular embodiments and manifestations of Judaism that are inclusive or exclusive of others. The word heimish was one example of a reference point that I continuously encountered but struggled to define or locate. Although its roots are in the term heim (Yiddish 'home'), the quality of being or feeling heimish has a more convoluted meaning. It encompasses a wide range of the Orthodox Jewish population; those who have a shared cultural background, outlook, or a similar level of religious observance and, as one participant described it, as 'people like us, who are on a similar level to us'.

A heimish atmosphere was the essence of many Shabbat dinners that I experienced over the year, but it was only when I arrived at the family home of a Satmar research participant that I grasped and experienced its tangible meaning; previously it had seemed like an abstraction. Upon opening the door, Mrs Fried led me through the hallway into a divided room with wooden flooring; the front housed a piano and settee, and the back held the grand dining table with a matching sideboard. The air was weighted with a musky feel, and the silver candelabra caught my eye, less for its ornateness and weight and more for the drops of candle wax that adorned and marked the solid wood cabinet 
beneath. The room told an ancient story; a narrative that was preserved in the leather-bound seforim ${ }^{15}$ behind me.

There were strands that ran across the Orthodox and Haredi frontiers and were available to any Jewish person in the local area, and these took the form of remarkable intra-group services as well as gemachim; ${ }^{16}$ which are both dedicated forms of chessed (Hebrew 'kindness') that operate in the Jewish topography. The services perform a unique role in catering for the needs of the religious constituency for whom outside agencies that are viewed as non-Jewish, or not frum, would be considered as culturally inappropriate. These include therapists, a swimming pool, special educational needs facilities, a family and children's centre, and hospital visitation groups. The gemachim consist of a continuously growing portfolio of resources that are freely available, or for a nominal charge to cover the expenditures incurred. These include laundry services, wedding dresses, foods and supplements which are considered to be health promoting, and medicines, to name a few. Whilst these services are available to all Jews in the area, I was told by Mr Attias that 'if you're not in the community, you probably wouldn't know about it'.

The socio-religious topography then demonstrates that territorial or geographical proximity to the Orthodox and Haredi precinct is one consideration, but arguably more important is the participation and conformity, and, by virtue of this, the circulation of knowledge that being in the community' bestows. This is, again, emblematic of Barth's theory of ethnic groups and boundaries and his argument that:

Ethnic groups are not merely or necessarily based on the occupation of exclusive territories; and the different ways in which they are maintained, not only by a once-and-for-all recruitment but by continual expression and validation, need to be analysed. What is more, the ethnic boundary canalizes social life - it entails a frequently quite complex organization of behaviour and social relations. (Barth I 998: I 5)

Differences in hashkofah extended beyond philosophical differences in Judaism, religious observance or customs, and to attitudes regarding the engagement with behaviours or conducts that are perceived as belonging to the

15 Hebrew 'religious texts or books'.

16 Hebrew 'an abbreviation of gemilut chassadim, acts of kindness'. 
non-Jewish or 'goyish'17 world. Exploring how young Haredi children engage with physical activity was an arena where the construction of qualitative knowledge became hindered by my liminal, 'Jew-ish' status. Whilst I had initially intended to understand how physical activity fits into Haredi Jewish childhoods by interviewing youths, my status often prevented this, probably because of my 'exposure' to other, contested, Jewish denominations as well as the broader outside world. The majority of my research participants, then, came to be Orthodox and Haredi mothers, consequently shifting the focus of the research.

However, in the eyes of some Haredi and Hassidish parents, it is more dangerous for their children to mix with Modern Orthodox or non-Orthodox children than non-Jews because of crucial differences in hashkofos. There are indeed differences in hashkofos between frum Jews and non-Jewish people, but because one group is Jewish and the other is not, there is a clear social boundary that justifies acting or thinking differently. But the issue of 'hashkofic contamination' - as one participant regarded it - is much greater because modern Orthodox Jews still define themselves as religiously observant, yet they may have a wildly different hashkofah and a less stringent approach to halacha $b^{18}$ than their frum or Haredi counterparts: so the boundaries effectively become more blurred.

Yehuda was one participant who had transitioned his children from a 'black'19 expression of Judaism and attendance at a private Haredi school to a state-aided Jewish school that was more modern and Zionist in its outlook. He remarked how intra-group differences can be demarcated by outlook and observance:

there are significant worries that if you speak to other children, the kid might hear things that are not quite appropriate for them - or ideas that are not [of the] correct hashkofah which might influence their children to take a non-Haredi lifestyle and they want to protect them against it.

The fear of 'hashfokic contamination'was a constant gradient between families, rather than it being an issue confined to the extremities of Jewish Orthodoxy. Describing herself as Modern Orthodox (but whose children attended schools

17 Derived from the Hebrew term goy(im) ('nation(s)'). Goyish is also used as a pejorative term for what is viewed as a non-Jewish conduct.

18 See Oring 1988 for a more in-depth discussion of the differences between 'traditional Orthodoxy' and Modern Orthodoxy in the US context, and the concern which Modern Orthodoxy presents for their 'traditional Orthodox' and Haredi counterparts.

19 This term was commonly used in the field-site as being Haredi, religiously right wing, or shtark, meaning strict. 
that were widely regarded as being more Haredi), one mother elucidated her concerns as to why differences in hashkofos are significant:

Mrs Harris: It's more to do with people coming from very different homes. It's hard to stop your kids being friends with people whose homes I'm not so keen on them going to. So either watching stuff that you don't want them to be watching, or wearing stuff that you don't want them to be wearing, or eating stuff that you don't want them to be eating.

By attending a particular educational establishment, her children would be encountering other children whose families upheld a similar hashkofah and socio-religious codes of conduct. But another participant faced the tension of realising that her eldest child would be more suited to an institution which was generally considered less Haredi by maintaining an emphasis on balancing secular and religious studies, but this was not an option, for fear that her younger children would consequently be 'thrown out' of the Haredi primary school they attended.

Whilst interviewing a Satmar mother, she commented that a defining principle of being Hassidish is what she described as a 'very insular outlook, and we do an awful lot of protecting ourselves from anything that might not be appropriate'. This extended to the use of a local organisation that claims to be 'cross-community', also serving the local non-Jewish population, and has an agenda to bridge informal Jewish and Zionist education with sports and social activities. When I asked if her children would use the service for physical activity and recreation, she replied:

Our children definitely not, other [Satmar] children presumably also not. This is going to sound extremely snobbish and I don't mean it the way it sounds; we try to be careful who they mix with, and if its going to be children who might introduce them to stuff that we're not very excited for them to know about, we'd like it to be with strict supervision and very carefully controlled. It sounds very snobbish and elitist, but we don't mean it like that, it's being exposed to the outside world.

Physical activity has been discussed as being contentious in Haredi educational institutions, perhaps because of a general resistance to a 'body culture' and the view that exercise is a 'gentile custom' (Hakak 2009). However, this quotation alludes to the possibility that childhood physical activity provisions in the 
'community' also bring unwanted and uncontrollable exposure to other Jewish modalities and customs.

Concerns about the degree of relation to Jewish families and institutions who identified with Zionism were common in Hassidish circles, and this was, for one participant, an issue when procuring funding from Jewish bodies for activities in the Hassidish neighbourhoods:

Mrs Leib: There were ideology issues, there was at the time some funding that came in through Zionist sources which was against their agreements.

Ben: Is that acceptable in this kind of community?

Mrs Leib: Not to my in-laws, anything that you take from a service that is available, you become behoven to; it's human nature. They do not ever want to be behoven to the Zionists because they were actually doing things against what is allowed. (Emphasised in interview)

Whilst Sarah Bunin has commented on the ways in which Orthodox cultural practices are maintained by upholding an ideology of distinction and separation from non-Orthodox Jews and non-Jews' (201 2: 7), there is evidently a potential for Orthodox and Haredi sub-groups to protect themselves from internal conflicts in worldviews, customs, and interpretations of observance. Although I was told that it was in nobody's interest for one Orthodox or Haredi group to marginalise another, with there being an exchange and reliance of services in between, marked distinctions were nonetheless at play. This reflects the notion described by Oliver Valins, where 'just as the dominant often seek to exclude others, minorities may likewise attempt to create and to defend their own identities and 'purified communities' (2003: I60).

What is conceived as a 'community' is a figment of the imagination, and, as Benedict Anderson has remarked, 'communities are to be distinguished, not by their falsity/genuineness, but by the style in which they are imagined' (2006: 6). The term 'community' has indeed been problematised in the broader academic discourse of intra-group relations, partly for its 'mythic value', which can give rise to a "misplaced belief in "community" and the "participation" that normally goes with it' (Cannon et al. 2014: 93). Moreover, as Roberto Barrios recently noted, “communities” are never static or bounded (either geographically or socially). Rather they are collectives that a) are in a constant state of emergence over time, and b) are shaped by dynamic, politically, and epistemically charged relationships' (20 I 4: 330). It is therefore the case that 'communities' are 
constantly being shaped and defined over time by continuously responding to what is perceived as being internal or external to the group.

Moving across homes and worldviews demonstrated how my own position(ing) in the field, to a certain extent, reflected degrees of difference and distinction between sub-groups in the Orthodox and so-called 'ultra-Orthodox' Jewish population. The risk posed by my own subjectivity as a 'Jew-ish' ethnographer and also the perceived threat of 'bashkofic contamination' from coreligionists upholds the notion of 'purity and danger', for 'where the lines of abominability are drawn heavy stakes are at issue' (Douglas 2002: I96).

\section{Coda}

Just months before I boarded my plane to Turku for the round-table discussion on 'Judaic Studies in the Nordic Countries Today', Dan Uzan was murdered whilst guarding Copenhagen's Great Synagogue, on I 5 February 2015. What makes this tragic incident even more harrowing is that it is just one of many targeted attacks against Jews in Europe over recent years. It followed the siege at a kosher grocery store in Paris where four Jewish men were murdered in January 2015, as well the unleashing of a Kalashnikov rifle at the Jewish Museum of Belgium in Bruxelles, killing four people in May 20 14. In between these fatal and targeted assaults were a string of anti-Jewish attacks, especially in the midst of the Israel-Gaza conflict of July 20I4, which led to worldwide protests and the attempted or actual firebombing of synagogues in France and Germany, as well as record levels of reported hate crimes against Jews in the UK (see Community Security Trust 2015).

It comes as no surprise then that disintegrating inter-group relations have come to define Jewish life in Europe, and my Jewish research participants were themselves fearful of an attack occurring locally. But attention should also be paid to intra-group dynamics and their nuanced differences. What is true of any 'community' is diversity, and we should think critically about this term being used to describe a sense of uniform participation.

Differences within and between Jewish Orthodox and Haredi sub-groups may result from differences in religious observance or customs, but also worldviews and outlooks that are feared as 'contaminating'. A singular expression of being a minority group or a context of marginality in the field-site then seems a less than accurate description of the composite Jewish population I encountered, and instead an issue of multiple marginalities were certainly at play. Considering this intra-group facet of Jewish life in Europe, I feel, will help 
us to better understand the current issues facing religious and ethnic minority populations more broadly in the Nordic countries.

The impetus to engage with Jewish ethnography as a $\mathrm{PhD}$ candidate provoked an experience that I naively did not foresee and neither can I forget; whilst I identified as being part of the same religion outside of the field, I was prohibited from doing so inside the field. I had become definitively 'neither fish nor fowl'. Conducting anthropology at home - or across homes - has, for me, clearly demonstrated how our own identities as researchers can enable as much as they can obstruct the potential for, or course of, ethnographic encounters. Postgraduate research students can indeed harness their contested positionalities within the 'field' to better understand the complexities that define, yet remain concealed within, a 'community'.

\section{Acknowledgements}

This research has been funded by the Wellcome Trust. With gratitude to C. Merli, Y. Egorova, T. Pollard for their supervision. Thanks to R. Illman, M. Vasenkari and B. Dahla for their support and suggestions with the presentation, and all participants of the round-table discussion on 'Judaic Studies in the Nordic Countries Today' (March, 20 I 5).

Ben Kasstan is a Wellcome Trust funded PhD Candidate in the Department of Anthropology at Durham University (UK). His current research explores how the UK's growing Haredi minority manifests in a culture of reproductive care, as well as their perceptions of state-provided maternal and infant health services. The Donner Institute has published his previous research into the ageing experience of Shoah survivors (in Religion and Food, Scripta Instituti Donneriani Aboensis, 26).

\section{References}

Alderman, Geoffrey, 2008. Controversy and Crisis: Studies in the History of the Jews in Modern Britain (Boston, Academic Studies Press)

Anderson, Benedict, 2006. Imagined Communities: Reflections on the Origin and Spread of Nationalism (London, Verso)

Aran, Gideon, Nurit Stadler, and Eyal Ben-Ari, 2008. 'Fundamentalism and the masculine body: the case of Jewish ultra-orthodox men in Israel', Religion, $38(\mathrm{I})$, pp. $25-53$

Arkin, Kimberly A., 20I 4. Rhinestones, Religion, and the Republic: Fashioning Jerwishness in France (Stanford University Press)

ASA, 20 I I. 'Ethical guidelines for good research practice' (Association of Social Anthropologists of the UK and the Commonwealth), <http://www.theasa.org/ downloads/ASA\%2oethics\%2oguidelines\%2020 I I.pdf> (accessed I7.7.2015) 
Barrios, Roberto, 20I4. "'Here, I'm not at ease": anthropological perspectives on community resilience,' Disasters, 38(2), pp. 329-50

Barth, Frederik, I 998. Ethnic Groups and Boundaries: The Social Organization of Culture Difference (Long Grove, Waveland Press, Inc)

Benor, Sarah Bunin, 20I 2. Becoming Frum: How Newcomers Learn the Language and Culture of Orthodox Judaism (New Brunswick, Rutgers University Press)

Boyarin, Jonathan, I 988. 'Waiting for a Jew: marginal redemption at the Eight Street Shul' in Between Two Worlds: Ethnographic Essays on American Jewry, ed. Jack Kugelmass (Ithaca, Cornell University Press), pp. 52-76

Bunin, Sarah, 20 I 2. Becoming Frum: How Newcomers Learn the Language and Culture of Oxford Judaism (New Brunswick, Rutgers University Press)

Cannon, Terry, Alexandra Titz, and Fred Krüger, 20 I 4. 'The myth of community?' in World Disaster Report 2014: Focus on Culture and Risk (International Federation of Red Cross and Red Crescent Societies), pp. 93-I I 9

Community Security Trust, 2015 . Antisemitic Incidences Report 2014, <https://cst.org. uk/docs/Incidents\%2oReport\%2020 I 4.pdf> (accessed 24.7.201 5)

Diamond, Etan, 2008. 'Religious microspaces in a suburban environment: the Orthodox Jews of Thornhill, Ontario' in Jerwish Topographies: Visions of Space, Traditions of Place, eds Julia Brauch, Anna Lipphardt, and Alexandra Nocke (Aldershot, Ashgate Publishing Company), pp. I I 9-38

Douglas, Mary, 2002. 'Land animals, pure and impure' in A Reader in the Anthropology of Religion, ed. Michael Lambek (Malden, Blackwell Publishing), pp. 194-209

Egorova, Yulia, 2009. 'The proof is in the genes? Jewish tesponses to DNA research', Culture and Religion, ro(2), pp. 159-75

Egorova, Yulia, and Shahid Perwez, 2013. The Jews of Andhra Pradesh: Contesting Caste and Religion in South India (Oxford University Press)

E1 Or, Tamar, I 994. Educated and Ignorant: Ultraorthodox Jerwish Women and their World, trans. Haim Watzman (Boulder, Lynne Rienner Publiations, Inc.)

Fader, Ayella, 2009. Mitzvah Girls: Bringing up the Next Generation of Hasidic Jews in Brooklyn (Princeton University Press)

Ferziger, Adam S., 2009. 'From demonic deviant to drowning brother: reform Judaism in the eyes of American orthodoxy', Jerwish Social Studies, I 5(3), pp. 56-88

Goldberg, Harvey E., I 972. Cave-Dwellers and Citrus-Growers: A Jewish Community in Libya and Israel (Cambridge University Press)

Hakak, Yohai, 2009 'Haredi male bodies in the public sphere: negotiating with the religious text and secular Israeli men', Journal of Men, Masculinities and Spirituality, 3(2), pp. 100-22

20 I . 'Egalitarian fundamentalism: preventing defection in the Israeli Haredi community', Journal of Contemporary Religion, 26(2), pp. 29 I-3 Io

Herman, Marilyn, 20 I 2. Gondar's Child: Songs, Honor, and Identity among Ethiopian Jerws in Israel (Trenton, Africa World Press)

Jackson, Michael, I 995. At Home in the World (Durham, Duke University Press) 
201 2. Between One and One Another (Berkeley, University of California Press) Jacobson-Widding, Anita, I983. Identity: Personal and Socio-Cultural, A Symposium, Acta Universitatis Upsaliensis, Uppsala Studies in Cultural Anthropology, 5 (Uppsala University)

Kahn, Susan Marta, 200o. Reproducing Jews: A Cultural Account of Assisted Conception in Israel (Durham, Duke University Press)

Kahn-Harris, Keith, 2014. 'Failing to capture the vibrancy of British Jewish life', Forward, 3 I.3.20 I 4, <http://forward.com/opinion/I 95560/failing-to-capturethe-vibrancy-of-british-jewish/> (accessed I.I I.2015)

Kahn-Harris, Keith, and Ben Gidley, 2o Io. Turbulent Times: The British Jewish Community Today (London, Continuum International Publishing Group)

Kasstan, Ben, 201 5. 'The taste of trauma: reflections of ageing Shoah survivors and how they (re)inscribe it with meaning' in Religion and Food, ed. Ruth Illman, Scripta Instituti Donneriani Aboensis, 26 (Turku, Donner Institute), pp. 349-65

Kugelmass, Jack, I 988. Between Two Worlds: Ethnographic Essays on American Jewry (Ithaca, Cornell University Press)

Merli, Claudia, 2008. Bodily Practices and Medical Identities in Southern Thailand, Acta Universitatis Upsaliensis, Uppsala Studies in Cultural Anthropology, 43 (Uppsala University)

Messerschmidt, Donald Alan, I98 I. Anthropologists at Home in North America: Methods and Issues in the Study of One's Own Society (Cambridge University Press)

Mitchell, William E., I 988. 'A goy in the ghetto: gentile-Jewish communication in fieldwork research' in Between Two Worlds: Ethnographic Essays on American Jewry, ed. Jack Kugelmass (New York, Cornell University Press), pp. 225-39

Myerhoff, Barbara, I 978. Number our Days (New York, Simon and Schuster)

Oring, Elliot, I 988. 'Rechnitzer rejects: a humor of modern Orthodoxy' in Between Two Worlds: Ethnographic Essays on American Jewry, ed. Jack Kugelmass (New York, Cornell University Press), pp. I48-6 I

Rashty, Sandy, 20 I 5. 'Exclusive: Reform rabbis approve streamlined conversion process', The Jewish Chronicle, I 4.7.20 I 5 <http://www.thejc.com/news/uk-news/I 396 I I/ exclusive-reform-rabbis-approve-streamlined-conversion-process $>$ (accessed I6.7.2015)

Seeman, Don, 2009. One People, One Blood: Ethiopian-Israelis and the Return to Judaism (New Brunswick, Rutgers University Press)

Sered, Susan Starr, I 996. Women as ritual experts: The religious lives of elderly Jewish women in Jerusalem (Oxford University Press)

Shapiro, Marc B., 201 5. Changing the Immutable: How Orthodox Judaism Rewrites its History (Oxford, The Littman Library of Jewish Civilization)

Simpson, Bob, 2006. "You don't do fieldwork, fieldwork does you": between subjectivation and objectivation in anthropological fieldwork' in The Sage Handbook of Fieldwork, eds Dick Hobbs and Richard Wright (London, Sage), pp. I 26-39 
Stadler, Nurit, 2013. 'Infiltrating fundamentalist institutions' in Qualitative Research: A Reader in Philosophy, Core Concepts, and Practice, eds Barbara Dennis, Lucinda Carspecken, and Phil F. Carspecken (New York, Peter Lang), pp. 342-57

2009. Yeshiva Fundamentalism: Piety, Gender, and Resistance in the Ultra-Orthodox World (New York University Press)

The United Synagogue, nd. 'Conversion', undated, <http://www.theus.org.uk/article/ conversion-2> (accessed I.I I.2015)

Tsuda, Takeyuki, 20 I 5 . 'Is native anthropology really possible?', Anthropology Today, 3 I (3), pp. I $4^{-I} 7$

Turner, Victor 2002. 'Liminality and communitas' in A Reader in the Anthropology of Religion, ed. Michael Lambek (Malden, Blackwell Publishing), pp. 358-74

Valins, Oliver, 2003. 'Stubborn identities and the construction of socio-spatial boundaries: Ultra-Orthodox Jews living in contemporary Britain', Transactions of the Institute of British Geographers, 28, pp. I 58-75

Weiss, Meira, 2002. The Body of the Nation: The Politics of the Body in Israeli Society (Stanford University Press)

Winston, Hella, 2005. Unchasen: The Hidden Lives of Hasidic Rebels (Boston, Beacon Press) 